\title{
An evaluation of the relevance of the Miles \& Snow strategic typology under present-day conditions of major environmental uncertainty - the emperor's new clothes or a paradigm shift?
}

\author{
H. Oosthuizen \\ Graduate School of Business, University of Stellenbosch, P.O. Box 610, Bellville, 7535 Republic of South Africa
}

Received May 1997

\begin{abstract}
The traditional approach to strategic management is an essentially rational approach. Present-day realities, however, are characterized by great uncertainty in the environment ('chaos'), making it difficult to achieve relatively stable strategic fit or organizational alignment in the longer term. The dilemma is one of a new paradigm or, will a more contemporary approach within the traditional framework suffice? The Miles and Snow strategic typology represents a case in point for the traditional approach. A comprehensive literature analysis of this approach suggests that the originally postulated framework still applies, even given today's change and uncertainty in the external environment. An empirical analysis of an integrated, and somewhat extended model of Miles and Snow was applied to the South African situation. It confirmed the Miles and Snow requirement for internal consistency but findings with regard to external fit proved inconclusive. South African organizations were found to have an internal and thus short-term focus, making them extremely vulnerable to global competition. The article concludes that strategy today should perhaps better be seen as an extention or redirection of conventional strategy into the realm of a more dynamic, flexible and adaptive approach to strategy, rather than as a total paradigm shift.
\end{abstract}

\section{Introduction}

The strategy of an organization is embodied in its 'prevailing pattern of moves and approaches' (Thompson \& Strickland, 1996: 2) and typically includes formulating a strategic intent, crafting a strategy to achieve the desired intent, implementing and executing the strategy efficiently and effectively, that is, continuously evaluating (control) performance. A 'good' strategy is considered to lead to a sustainable competitive advantage, thus improving organizational output performance. This can only be achieved with situational fit, that is, the 'good' strategy is well-matched to the organization's external as well as internal situation (Thompson \& Strickland, 1996: 53-54).

The approach described in the above paragraph has been termed as 'conventional' strategic management and constitutes a traditional and essentially rational approach to strategic management (Stacey, 1996: chapter 5). Present-day realities, however, are considered vastly different to many of those assumptions and philosophies underlying conventional strategic wisdom. The external environment is characterized by instability, volatility and major turbulence, that is, basically unpredictable. Changes are non-linear and because of the existence of positive feed-back loops, these changes are being amplified into explosive and unintended situations. This modern-day environmental complexity may be defined as bounded chaos, referred to as the Mandelbrot set (Wheatley, 1994: 128).

Given the 'chaotic' conditions it is considered practically impossible to achieve the strategic holy grail of relatively long-term stable situational fit and strategy formulation thus develops into a continuous state of flux and change, rendering it imperative to review the validity of the conventional approach to strategy. Consequently, new paradigms are claimed to emerge, known as Post Modernist, Extraordinary Management or Unconventional Strategic Wisdom (Stacey, 1996: part 4). The corner-stone of strategy seems to be found in 'split rather that fit' and thus dealing with open-ended issues
(Camillus \& Datta, 1991) rather than structured and integrated approaches.

The dilemma confronting academics and practitioners alike is whether this proposed new approach to strategy really constitutes a new strategic paradigm, or is it merely a matter of 'new clothes for the emperor'? - the conventional approach remains valid but it needs to adopt and adapt to also provide for some new and contemporary developments. With this question in mind the initial research objective was to empirically test the validity and applicability of a conventional approach to formulating business strategy in the turbulant present-day environmental conditions in South Africa. The results proved to be inconclusive. Subsequently, after various analyses were conducted to ensure statistical acceptability and correct treatment of the empirical data, it was considered adviseable to revisit the conventional approach to formulating business strategy. From the above sequence of research steps it eventually became possible to reach some conclusions, albeit tentative, about the approach of South African business to formulating a business strategy.

\section{Conventional strategic approaches}

Three conventional strategic styles have become synonymous with the relationship between the overall external environment and the strategy of the organization: Miles \& Snow (1978), Mintzberg \& Waters (1985) and Gould \& Campbell (1987). The Miles \& Snow typology, however, is unique because it views the organization as a complete and integrated system and presents a particularly useful theoretical framework for analysing the ways in which organizations dynamically interact with their environments (McDaniel \& Kolari, 1987: 19) and has consequently generated a large amount of interest, investigation, controversy and support (Conant, Mokwa \& Varadarajan, 1990: 365). It has enjoyed widespread application in strategy and has the ability to encapsulate strategy at a level of abstraction sufficient to apply across a wide variety of organizations and industries, including the public sector (Nutt \& Bachoff, 1992: 73). It has furthermore 
been suggested that there is a general congruence between the Miles \& Snow typology and Porter's generic competitive strategies, namely cost leadership and differentiation (Shortell \& Zajac, 1990: 817). For the above-mentioned reasons it was decided to confine this investigation to the Miles \& Snow typology of strategies.

Miles \& Snow (1978: 8-11) based their initial research on the following industries: college textbook publishing, electronics, food processing and hospitals. Their relatively complex strategic concept adopts the systems approach and proposes that organizational managers develop enduring patterns of strategic behaviour (identified as Prospectors, Defenders, Analyzers and Reactors) that actively co-align (or link) (adaptive cycle) the internal organizational domains (structure and process variables) of entrepreneurial, engineering and administrative with their perception of the external environment. Miles \& Snow thus extends the concept of 'strategic choice' in order to achieve fit as proposed by Child (1972) and by clear implication also accept Child's view on the important moderating role played by political forces and power-holders in deciding upon the course of strategic action. Finally, Miles \& Snow suggested that any of the strategic behaviour types would perform (output performance) equally well in any industry, provided that the strategy is well implemented. Ostensibly this contention appears to be inconsistent with the generally accepted conventional view that a particular environment favours a certain type of strategic behaviour.

\section{Empirical assessment of the Miles \& Snow strategic typology}

\section{Problem statement}

The concept of 'problem' can best be described as the unknown condition (or uncertainty) causing a state of unrest or disorder (Kress, 1982: 48). Nearly 20 years have elapsed since Miles \& Snow (1978) proposed their strategic typology. However, despite their holistic approach and the theoretically acclaimed importance of viewing an organization as a total entity, examination of the typology tends to concentrate on compartmentalized aspects thereof and apparently do not view the organization as a complete and integrated system of interlinked and co-ordinated strategies and actions aimed at achieving a desired output performance. A limitation of this kind was already observed in the early 1980s (Snow \& Hrebiniak, 1980: 333; Hambrick, 1981: 269) and still seems to persist (Conant et al., 1990: 379). This paucity of information with regard to an overall empirical assessment of the Miles \& Snow typology is the problem, or uncertainty/disorder addressed in this article.

\section{Research objectives and limitations of study}

The primary research objective of this study is to investigate the general applicability of the integrated synthesis of the Miles \& Snow strategic framework; as such it adopts the coarse-grained methodology to strategy research (Harrigan, 1983: 399). Secondary objectives are to establish and describe the framework (i) under turbulent environmental conditions; (ii) as it currently exists in South Africa; and (iii) to introduce the concepts of inarket orientation and marketing approach into the Miles \& Snow framework. Market orientation, often regarded as a proxy for external orientation, is particularly important in evaluating organizational alignment with the environment because increased levels of markel orientation has been associated with improved business profitability (Narver \& Slater, 1990: 32). Although not to be regarded as an objective per se the research also included the Porter generic strategies (Porter, 1980) in an attempt to integrate these into the Miles \& Snow typology (also see in this regard Seger, 1989).

Two limitations of this study must be recognized. Firstly, the primary emphasis is on the extreme types of the Miles \& Snow strategic typology namely, Prospectors and Defenders, in an attempt to illustrate how integrated but vastly different strategic typologies interact with diverse environmental conditions. Secondly, the inter-connectedness between environment, business strategy, functional emphasis and their collective extention towards specific functional actions, is biased to marketing elements. The marketing function is considered to provide a 'natural' link with the concept of market/ external orientation and it has furthermore long been recognised that

'... a distinct trend (exists) in business practice: the integration of marketing planning into the strategic planning process' (Abell \& Hammond, 1979: xi).

\section{Research design}

An exploratory empirical survey was conducted during 1994 and was confined to judgmentally selected service organizations in the Western Cape Province. The study was purely descriptive in nature and could not make statistical claims towards generalization or to have any predictive capabilities (Laubscher, 1994).

Notwithstanding the limitation of being descriptive only, the survey findings established a broadly-based support for a research hypothesis which postulated that: "converse environmental conditions will result in organizations adopting different integrated strategic hierarchical structures and functional actions', that is supporting the Miles \& Snow framework.

Nevertheless, the pilot study did highlight some apparent contradictions and as such suggested the need for a more indepth, statistically defendable sample and broader investigation of similar nature. Furthermore, the pilot study, because it employed both a mail survey as well as personal interviews, provided valuable guidance for future questionnaire construction, particularly in the areas of measuring environmental turbulence and identifying marketing variables.

Subsequently the pilot study was followed by a comprehensive survey during the three months of May, June and July 1995. A self-administered postal questionnaire was utilized.

The questionnaire consisted of six sections and contained questions relating to level of environmental predictability, strategic type, relative importance of functional activities, management orientation, marketing approach and marketing activities and output performance.

Environmental predictability (proxy for level of turbulence) was established in terms of various aspects, for example supplier changes, competitors actions, customer needs, financial markets, changes in technology, and political situation.

Because patterns of organizational response to environmental conditions is determined not so much by the objective characteristics of the environment-organization interactions 
as by managerial perceptions of critical external areas (Hitt, Ireland \& Palia, 1982: 270) the concept of perceived environmental uncertainty (PEU) was assumed.

Various approaches may be administered to identify the intended strategic business type (Snow \& Hambrick, 1980: 534-535). This study employed the self-typing paragraph approach which has been widely used to investigate the Miles \& Snow typology (Conant et al., 1990: 368). This approach requires that respondents read short paragraph-length descriptions of each of the four strategies, and then select that one which best describes their organizational strategy. The limitations of this approach has been recognized but investigation reveals that a more sophisticated multi-item measure is still very much in its formative stages and in need of additional field testing and measure refinement (Conant et al., 1990: 376).

The questionnaire sections on functional and marketing activities listed organizational functions and marketing elements typically performed by an organization and requested respondents to indicate the degree of strategic and competitive significance their organizations attach to each.

The questions relating to managerial orientation endeavoured to establish the extent of market or external orientation of the organization. As point of reference the work of Narver \& Slater (1990) was utilized, the original questionnaire having kindly been made available by Professor Slater. The tacit assumption in the reliance on the Narver \& Slater questionnaire is an acceptance of their development of a valid measure of market orientation.

Approaches to marketing was based on the research by Hooley, Lynch \& Shepherd (1990) and identified three distinct marketing typologies, namely Sales supporters, Departmental marketers and Marketing philosophers. Respondents were required to indicate which one of three descriptions of the typologies most closely fit their organization's orientation towards marketing.

The output performance section of the questionnaire related performance to the past financial year's performance relative to major competitors (much worse, worse, the same, better, much better) and included measures of profit, sales volume, market share, return on investment and cash flow. Subjective measures of this nature are commonly used and studies have established a strong correlation between subjective assessment and the objective measurements (Dess \& Robinson, 1984; Pearce, Robbins \& Robinson, 1987).

In the sections relating to perceived environmental uncertainty, relative importance of functional activities and marketing elements, as well as organizational orientation, respondents were asked to indicate on a five-point scale the extent to which the answer to each of the questions existed within their organizations.

A nationally representative probability sample consisting of medium and large organizations was drawn from the data bank of the Bureau of Market Research at the University of South Africa, Pretoria. It was confined to the manufacturing division (3) of the Standard Industrial Classification (SIC), Altogether 1860 questionnaires together with a covering letter explaining the purpose of the survey, were mailed to chief executives of the selected organizations towards the end of
April 1995. By the end of July (target date), 211 usable replies had been received, a response rate of $11.3 \%$.

\section{Data processing and analysis}

The data were summarized and tabulated by utilizing the computer software Statgraphics Version 7. Apart from calculating frequencies and relative frequencies, a number of contingency tables were constructed as discriptive tools. The results are summarized in Tables 1 to 7 .

\section{Research results}

The findings of the survey are structured firstly around the general Overall findings, and are then followed by a discussion of each one of the major themes, namely: Perceived environmental uncertainty, Business strategy, Functional importance, Organizational orientation and Marketing typology, Marketing activities and Output performance.

\section{Overall findings}

Overall it was established that South African organizations do not seem to align/fit their business strategy with diverse external environmental conditions. Nevertheless, high levels of market (external) orientation were claimed. Internally organizations follow a very clear pattern of structural fit, suggesting a high degree of internal consistency and also adopting a sophisticated marketing approach. This resulted in such organizations outperforming others on all measures of output performance criteria.

\section{Perceived environmental uncertainty (PEU)}

As can be seen form Table 1 about one third (31\%) of respondents perceived their environmental conditions as being relatively predictable (stable), whilst $28 \%$ viewed it as being relatively unpredictable (turbulent/volatile). Some $41 \%$ were clearly uncertain and their environments can at best be described as 'average'.

\section{Business strategy}

According to conventional logic a high level of PEU will be associated with a Prospector strategy and a low level of PEU with a Defender strategy. From Table 2 it is apparent that the Prospector strategy is indeed most popular (36\%) when PEU is high but is closely followed by the Analyzer (33\%) strategy. This, however, is not particularly surprising as the Analyzer may be regarded as being close to the Prospector in conditions of relatively high PEU. The high support for the Defender (28\%) strategy is somewhat unexpected under conditions of a relatively unpredictable environment. Table 2 furthermore shows that the Prospector and Analyzer

\begin{tabular}{lc}
\hline $\begin{array}{l}\text { Table } 1 \text { Perceived environmental } \\
\text { uncertainty (PEU) }\end{array}$ \\
\hline Nature of PEU & $\%$ \\
Relatively predictable & 31 \\
Relatively unpredictable & 28 \\
Average & 41 \\
Total & 100 \\
\hline
\end{tabular}




\begin{tabular}{|c|c|c|}
\hline \multirow[t]{3}{*}{ Strategic typology } & \multicolumn{2}{|c|}{$\begin{array}{c}\text { Percejved environmental } \\
\text { uncertainty }\end{array}$} \\
\hline & $\begin{array}{l}\text { Relatively } \\
\text { predictuble }\end{array}$ & $\begin{array}{c}\text { Relatively } \\
\text { unpredictable }\end{array}$ \\
\hline & $\%$ & $\%$ \\
\hline Defender & 17 & 28 \\
\hline Prospector & 42 & 36 \\
\hline Analyzer & 39 & 33 \\
\hline Reactor & 2 & 3 \\
\hline$\overline{\text { Total }}$ & 100 & 100 \\
\hline
\end{tabular}

strategies also dominate under conditions of low PEU, in fact, at even higher percentage levels than for a relatively unpredictable environment. From the findings it would thus appear that South African organizations do not clearly align their strategic typology to fit with diverse environmental conditions.

As far as strategic effort to gain and maintain competitive advantage is concerned, Table 3 reflects an overwhelming support, notwithstanding the nature of PEU, for Porter's differentiation strategy - building customer perceptions of superior product quality, design or service. In combination with the dominant Prospector strategy, this suggests a broad product domain (total market) rather than a focus (Boyd, Walker \& Larréché, 1995: 230), in which the business avoids direct confrontation with its major competitors by concentrating on more narrowly defined markets.

Perceived environmental uncertainty, business strategy and functional importance

From Table 4 it may be gleaned that four organizational functions seem to dominate (significant) under any type of

\begin{tabular}{|c|c|c|}
\hline \multirow[t]{3}{*}{ Generic strategy } & \multicolumn{2}{|c|}{$\begin{array}{c}\text { Perceived environmental } \\
\text { uncertainty }\end{array}$} \\
\hline & $\begin{array}{l}\text { Relatively } \\
\text { predictable }\end{array}$ & $\begin{array}{c}\text { Relatively } \\
\text { unpredictable }\end{array}$ \\
\hline & $\%$ & $\%$ \\
\hline Low cost & 26 & 19 \\
\hline Differentiation & 74 & 81 \\
\hline Total & 100 & 100 \\
\hline
\end{tabular}

extreme level of PEU, namely: Financial management (78/ 74\%), Marketing (86/77\%), Production (78/82\%) and Purchasing $(82 / 73 \%)$. Under conditions of a relatively predictable environment the functions of General management (72\%) and Logistics (71\%) also seem to emerge as being rather significant. It is furthermore noteworthy that Research and Development (R \& D Technology) (28\%), Distribution $(17 \%)$ and Human resources $(17 \%)$ are seen to be relatively insignificant under higher levels of PEU.

South African organizations don't seem to adopt very different structures of functional importance under diverse conditions of PEU. This finding, however, must be viewed against the background of very similar business strategies being pursued under these diverse conditions of PEU.

\section{Perceived environmental uncertainty, organizational orienta- tion and marketing}

The claimed level of market orientation is high for any condition of PEU. Refer to Table 5. Perhaps contrary to what could be a general expectation, it is even slightly higher in the case of a relatively predictable environment $(61 \%)$ than compared to an unpredictable environment (47\%). It may, however, be argued that the very higher level of external (market) orientation leads to a better understanding and appreciation of

\begin{tabular}{|c|c|c|c|c|c|c|}
\hline \multirow{4}{*}{$\begin{array}{l}\text { Organizational } \\
\text { function }\end{array}$} & \multicolumn{6}{|c|}{ Perceived environmental uncertainty } \\
\hline & \multicolumn{3}{|c|}{ Relatively predictable } & \multicolumn{3}{|c|}{ Relatively unpredictable } \\
\hline & \multirow{2}{*}{$\frac{\text { Insignificant }}{\%}$} & \multirow{2}{*}{$\frac{\text { Neutral }}{\%}$} & \multicolumn{2}{|c|}{ Significant Insignificant } & \multirow{2}{*}{$\frac{\text { Neutral }}{\%}$} & \multirow{2}{*}{$\frac{\text { Significant }}{\%}$} \\
\hline & & & $\%$ & $\%$ & & \\
\hline General management & 6 & 22 & 72 & 7 & 26 & 67 \\
\hline Financial management & 6 & 16 & 78 & 7 & 19 & 74 \\
\hline Marketing & 0 & 14 & 86 & 7 & 16 & 77 \\
\hline Market research & 21 & 31 & 48 & 26 & 35 & 39 \\
\hline R/D (Technology) & 16 & 20 & 64 & 28 & 21 & 51 \\
\hline Production & 0 & 22 & 78 & 4 & 14 & 82 \\
\hline Distribution & 9 & 27 & 64 & 17 & 35 & 48 \\
\hline Legal issues & 52 & 28 & 20 & 56 & 33 & 11 \\
\hline Human resources & 8 & 33 & 59 & 17 & 32 & 51 \\
\hline Government relations & 34 & 35 & 31 & 34 & 43 & 23 \\
\hline Logistics & 9 & 20 & 71 & 12 & 33 & 55 \\
\hline Purchasing & 3 & 15 & 82 & 3 & 24 & 73 \\
\hline Special value-added services & 15 & 32 & 52 & 14 & 43 & 43 \\
\hline
\end{tabular}


Table 5 Organizational orientation according to perceived environmental uncertainty

Stalements regarding organizational orientation

Perceived environmental uncertainty

\begin{tabular}{cccccc}
\hline \multicolumn{3}{c}{ Relatively predictable } & \multicolumn{3}{c}{ Relatively unpredictable } \\
\hline Disagree & Neutral & Agree & Disagree & Neutral & Agree \\
\hline$\%$ & $\%$ & $\%$ & $\%$ & $\%$ & $\%$ \\
\hline 6 & 25 & 69 & 11 & 33 & 56 \\
6 & 15 & 79 & 3 & 42 & 55 \\
9 & 31 & 60 & 19 & 21 & 60 \\
28 & 7 & 65 & 22 & 24 & 54 \\
2 & 21 & 77 & 7 & 27 & 66 \\
17 & 26 & 57 & 17 & 28 & 55 \\
23 & 17 & 60 & 26 & 33 & 41 \\
8 & 24 & 68 & 17 & 35 & 48 \\
18 & 31 & 51 & 26 & 43 & 31 \\
17 & 31 & 52 & 24 & 36 & 40 \\
. & & & & & \\
23 & 41 & 36 & 35 & 37 & 28 \\
18 & 31 & 51 & 21 & 31 & 48 \\
25 & 29 & 46 & 31 & 34 & 35 \\
\hline 16 & 23 & 61 & 20 & 33 & 47 \\
\hline
\end{tabular}

environmental conditions and thus management's perception that the environment is indeed relatively predictable? A case in point may be the fact that a well-designed marketing intelligence gathering system is regarded as more important under a lower level of PEU (46\%) than under a higher level of PEU (35\%)?

Marketing typology is reflected in Table 6 and it appears that the sophisticated 'Marketing philosophers' approach clearly dominates. This suggests that the marketing function is regarded as a dominant function and is actively involved in overall organizational planning. This is not the position with the 'Sales supporters' and 'Departmental marketers' approaches where the marketing function would be considered to be 'weak'. The dominance of Marketing philosophers is thus in line with the relative overall importance afforded to the marketing function (see previous paragraph: 'perceived environmental uncertainty business strategy and functional

Table 6 Marketing approach according to perceived environmental uncertainty

\begin{tabular}{lcc}
\hline Marketing approach & \multicolumn{2}{c}{ Perceived environmental uncertainty } \\
\cline { 2 - 3 } & $\begin{array}{c}\text { Relatively } \\
\text { predictable }\end{array}$ & $\begin{array}{c}\text { Relatively } \\
\text { unpredictable }\end{array}$ \\
\cline { 2 - 3 } & $\%$ & $\%$ \\
\hline Sales supporters & 8 & 26 \\
Departmental marketers & 38 & 25 \\
Marketing philosophers & 54 & 49 \\
\hline Total & 100 & 100 \\
\hline
\end{tabular}

importance') as well as the claimed high level of market orientation referred to above.

\section{Perceived environmental uncertainty and marketing activities}

Two marketing activities are clearly very important under any condition of PEU, namely: service/product line breadth and service/product quality. The broad service/product line is consistent with a Prospector strategy (broad scope) whilst emphasis on quality also fits with a Prospector strategy as well as with a Differentiation strategy and the Marketing philosophers approach.

The relative importance of price and price level under higher conditions of PEU is to be expected given that the organization would wish to recoup funds as soon as possible. It is furthermore consistent with the Prospector price policy that 'price levels relative to competitors are high' (Boyd, Walker \& Larréché, 1995: 237).

Given the previously stated assumption that the perception of a relatively predictable environment may be the result of a higher real level of market/external orientation, may account for the fact that 'marketing's involvement with corporate strategy' and 'marketing's working relationship with other functions', is rated as rather important under conditions of relatively predictable environmental conditions.

Generally speaking, the overall structure of marketing activities is fairly consistent for any condition of PEU. This, however, must again be viewed against the background of very similar business strategies being pursued under diverse conditions of PEU. 


\begin{tabular}{|c|c|c|c|c|c|c|}
\hline \multirow[t]{4}{*}{ Marketing activity } & \multicolumn{6}{|c|}{ Perceived environmental uncertainty } \\
\hline & \multicolumn{3}{|c|}{ Relatively predictable } & \multicolumn{3}{|c|}{ Relatively unpredictable } \\
\hline & $\begin{array}{c}\text { Not } \\
\text { important }\end{array}$ & 'Average' & $\begin{array}{l}\text { Extremely } \\
\text { important }\end{array}$ & $\begin{array}{c}\text { No } \\
\text { important }\end{array}$ & 'Average' & $\begin{array}{l}\text { Extremely } \\
\text { important }\end{array}$ \\
\hline & $\%$ & $\%$ & $\%$ & $\%$ & $\%$ & $\%$ \\
\hline Service/product line breath & 5 & 20 & 75 & 2 & 25 & 73 \\
\hline Technical sophistication of services/products & 9 & 34 & 57 & 21 & 28 & 51 \\
\hline Service/product quality & 0 & 3 & 97 & 3 & 3 & 94 \\
\hline $\begin{array}{l}\text { New service/product development, improvements and } \\
\text { extensions }\end{array}$ & 8 & 25 & 67 & 10 & 31 & 59 \\
\hline Overall price level & 6 & 25 & 69 & 5 & 15 & 80 \\
\hline Overall pricing importance & 6 & 26 & 68 & 2 & 19 & 79 \\
\hline Forward vertical integration & 31 & 37 & 32 & 18 & 55 & 27 \\
\hline Trade promotions & 38 & 28 & 34 & 40 & 33 & 27 \\
\hline Location and distribution innovations & 28 & 31 & 41 & 36 & 24 & 40 \\
\hline Mass advertising & 46 & 31 & 23 & 62 & 17 & 21 \\
\hline Sales promotions & 29 & 31 & 40 & 50 & 15 & 35 \\
\hline Personal selling & 18 & 12 & 70 & 29 & 9 & 62 \\
\hline Direa mail & 80 & 15 & 5 & 86 & 10 & 4 \\
\hline Telephone solicitation & 66 & 15 & 19 & 67 & 15 & 18 \\
\hline Point of Sale (P.O.S.) material & 49 & 20 & 31 & 51 & 25 & 24 \\
\hline Sales training for all employees & 34 & 29 & 37 & 43 & 29 & 28 \\
\hline Sales training for customer contact staff & 12 & 17 & 71 & 24 & 26 & 50 \\
\hline Sales management & 8 & 14 & 78 & 9 & 26 & 65 \\
\hline Competurized customer information systems & 20 & 12 & 68 & 17 & 27 & 56 \\
\hline Public relations & 18 & 26 & 56 & 26 & 26 & 48 \\
\hline Marketing research & 17 & 34 & 49 & 17 & 35 & 48 \\
\hline Environmental scanning & 25 & 23 & 52 & 30 & 37 & 33 \\
\hline Marketing's involvement with corporate strategy & 9 & 18 & 73 & 15 & 33 & 52 \\
\hline Marketing's working rel ationship with other functions & 11 & 15 & 74 & 10 & 35 & 55 \\
\hline
\end{tabular}

\section{Organizational output performance}

The business strategy-combination of Prospector-differentiator consistently outperformed any other combination under diverse environmental situations and on all output performance criteria.

\section{Discussion}

The finding that South African organizations do not appear to fit their business strategies to a particular set of external environmental conditions, together with the generally accepted convention that this should indeed be the case, raises the question as to the validity of the measuring instrument utilized for perceived environmental uncertainty (PEU).

PEU was measured according to an adapted format of the original instrument used by Miles \& Snow. Statistical analyses were subsequently conducted to determine if varying and selected elements of PEU would render different outcomes with regard to choice of business strategy. This proved not to be the case and thus confirmed the observation that organizations do not clearly align their business strategy with diverse environmental conditions.
The overall domination of the Prospector strategy (in tandem with the Analyzer strategy) may be explained by the consideration that this strategy is particularly well suited to an unstable and rapidly changing environment as is currently experienced in South Africa, that is even 'stable' conditions in South Africa are apparently that turbulent that it indeed 'enforces' a Prospector strategy? However, it must be realized that in portfolio terms Prospectors are either 'problem children' or 'stars' - businesses which require large amounts of cash and are thus 'cash users' rather than generators of cash. Relative to other strategic typologies the Prospector furthermore tend to render the lowest ROI (Boyd et al.,1995: 230).

The broad-based Differentiation strategy favoured by organizations implies a high-cost approach seeking confrontation (a high risk approach) in a broadly defined (all major segments) market domain. Although seemingly supported by a relatively high price-structure, this approach may not necessarily be viable in the longer term.

The overall strategic typology of South African organizations to combine Prospector and Differentiation approaches on a broad-based domain need not be condemned per se. In fact, it has been found that 'Comparison of the evaluated profile of Differentiation with the profile of the Prospector 
reveals no major differences' (Segev, 1989: 496). However, when such a cash user, low ROI and high-cost approach is apparently divorced from any clear environmental fit, it is simply ineffective in its execution and thus potentially fatal to the existence of the organization, particularly under conditions of increasing global competition such as South Africa is currently experiencing.

Given the dominance of the Prospector-Differentiator strategy it is furthermore evident that there is considerable internal structural fit or consistency amongst the organizations surveyed. Basically four functions dominate: Financial management, Production. Purchasing and Marketing whilst within marketing, major emphasis is concentrated on width of service product line and quality of service product, organizations claim a high level of market orientation and follow the sophisticated Marketing philosophers approach to marketing strategy. The existence of this particular internal structure outperforms all other combinations.

From the above discussion it clearly emerges that organizations put great emphasis on internal fiv/consistency but seem to be at variance with external fit. This management approach stresses efficiency, that is, doing things right (the importance of the financial, production and purchasing functions underlines this), but usually at the expense of effectiveness - doing the right things in terms of the environment.

In conclusion, the findings of the empirical survey failed to provide conclusive evidence for an overall assessment of the validity of an integrated synthesis and holistic view of the Miles \& Snow framework for business strategy. For this reason and because statistical analyses could not be render any explanation for the discrepancies, the typology (as outlined at the outset of this article) was revisited in some depth.

\section{Miles \& Snow typology revisited}

The overall validity of the Miles \& Snow strategic typology as well as the system-elements thereof have been scrutinized by various researchers. An investigation by Shortell \& Zajac (1990) took a highly statistical multiple indicators approach and concluded that overall the results provide strong support for the measurement validity of Miles \& Snow's (1978) strategic types (Shortell \& Zajac, 1990: 828). A similar conclusion was reached by Conant et al. (1990) in their multiple measures-based study.

The relationship, as intended by Miles \& Snow, between the nature of the external environment and its impact on the selection of the most appropriate strategy, appears to be a somewhat contentious issue (Hambrick, 1983: 7). The confusion seems to emanate from the Miles \& Snow observation that any one of the three more stable archetypal styles (Prospectors, Defenders and Analyzers) are equally likely to perform well in any industry (Miles \& Snow, 1978: 14). This contention by Miles \& Snow must, however, be evaluated within a much broader context.

In an early article Miles \& Snow (Miles, Snow \& Pfeffer, 1974: 263) clearly state that they have 'no doubt' that organizations adjust their strategies to environmental demands whilst in their landmark work, there are clear references to the link between the particular nature of the environment and a specific type of strategy, for example '... the dynamic process of adjusting to environmental change and uncertainty ... is enormously complex' (1978: 3). Furthermore, the Diagnostic checklist (1978: 109) clearly links 'toward which type (of strategy) should I begin to move' if the answer is ' $n o$ ' to the question 'Is what I am (in terms of strategy) likely to remain viable given the foreseeable environmental conditions?' Also, for example, it is clearly stated that Defenders perceive their environments to be relatively stable (1978: 37 ) whilst the Prospector's domain is regarded to be in a 'continuous state of development' (1978: 56) and 'dynamic in nature' (1978: 58). In a subsequent article Miles \& Snow (1984: 10) again re-affirm that 'successful organizations achieve strategic fit with their market environments ...'

A possible explanation for any confusion could be found in the use of the word industry. It must be appreciated that environmental conditions may differ considerably for different organizations within a given industry. This is so because organizations by interacting with their environments can create their own special environment (in a particular industry) through a series of choices regarding inter alia markets, products, etc. (Miles \& Snow, 1978: 5-6), as well as top management's perception of the environment rather than any 'objective' indicator of environmental conditions (Miles et al., 1974: 257). In other words, although any one of the three stable types may perform equally well in a given broad industry, the specific strategic type adopted and adhered to is shaped and dictated by the circumstances pertaining in the chosen industry niche, thus clearly linking the particular nature of the environment and a specific strategic type.

Finally, well-known contemporary authors acknowledge the link between the Miles \& Snow strategic topology and the nature of the environment, for example:

- 'Miles \& Snow proposed that corporations can be organized according to four types of strategies: prospector, analyzer, defender, and reactor. Strategy formulation is the responsibility of top management and may thus be related to environmental conditions that are similar to interpretation modes' (Hardy, 1994: 89).

- Referring to the Miles \& Snow business strategies Boyd et al.,(1995: 226) observed that '.. we examine any number of generic competitive strategies a business might pursue, and the environmental circumstances where each is most likely to be appropriate'.

With regard to the environment per se it is noteworthy that throughout their text (1978) Miles \& Snow stress the role of change and uncertainty (in fact, the original four industries which constituted the basis for this research, was chosen for this very reason! - see Miles \& Snow, 1978: 9-11) in the environment and its impact on strategy, even devoting a full chapter to this issue: prior theory and research (1978: Chapter 14). Furthermore, also Mintzberg (1978: 934-948) too described quick and radical strategic change during periods of environmental turbulence. In fact, according to Nakamura it is claimed that

'since its birth, strategic management has been referred to as the discipline of corporate innovation to cope with the discontinuous and/or turbulent corporate environment' (1997:4).

The concept of major change appears not at all unconventional and the modern-day hype about chaos, change 
and strategic transformation may not be so new and controversial after all!

Turning next to internal fit, or 'the process of organizational adaptation' as defined by Miles \& Snow (1978: chapter 2), concerns managing (via the 'adaptive cycle') the internal interdependencies of functions, structures and processes in order to align (internal consistency) the total organization with its environment, given a particular strategic posture.

Snow \& Hrebiniak (1980) related this aspect of internal consistency to distinctive competencies which they investigated through an analysis of the following ten functions: general management, financial management, marketing/selling, market research, product research and development, engineering, production, distribution, legal affairs and personnel. Broadly speaking their findings suggest identifiable but different configurations or internal patterns of distinctive competencies for the various strategic types. Studies by Hambrick (1982) as well as McDaniel \& Kolari (1987) also indicate that the Miles \& Snow strategic types differ in functional strategy, expertise and competencies.

Two studies investigated the Miles \& Snow strategic typology and its particular relationship to the marketing function. McDaniel \& Kolari (1987) established that the various marketing elements differ considerably among the strategic types whilst Conant et al. (1990: 376) rated the strategic types in their relative degree of marketing related competencies as: Prospector $\rightarrow$ Analyzer $\rightarrow$ Defender $\rightarrow$ Reactor, that is, each strategic type emphasizes different aspects of marketing.

The above-mentioned studies provide ample support for the Miles \& Snow contention that a particular and unique internal pattern or system exists to support strategic style to align the organization with its environment.

Finally, the Miles \& Snow typology must be viewed in relation to organizational output performance. Miles \& Snow (1978) postulated that the various strategic types would perform equally well in any industry. As was indicated previously, however, the term industry could (and probably does) imply different external conditions to different organizations. It would thus not be unrealistic to expect that, given different environmental niches and resultant strategies, different levels of output may be achieved.

In this regard a study by Snow \& Hrebiniak (1980) established that Defenders, Prospectors and Analyzers consistently outperform Reactors in competitive environments, but not in an environment that is highly regulated. Hambrick (1983: 17) found statistically significant differences in the performance (profitability, cash flow and market share) of Prospectors and Defenders as it relate to external characteristics such as life cycle stage (growth versus mature) and innovative or non-innovative. Very broadly it may be concluded that Prospectors are at a disadvantage (ROU/CF) in every type of environment, but they are at an advantage in gaining market share in innovative environments (1983: 21). A study by Conant et al. (1990: 377) found that their results regarding strategic type and output performance were consistent with the general notion that Prospectors, Defenders and Analyzers perform equally well but that Reactors, due to their inconsistent pattern of adaptation to the environment, perform relatively poorly. Although no clear pattern emerges it would seem reasonable to accept that different strategic typologies may be associated with different levels of output performance.

In conclusion, the above in-depth literature discussion and analysis of the Miles \& Snow approach concurs with the broad description of the strategic typology as outlined at the outset of the article. Against this background it is now possible to comment more veritably, albeit tentatively, on the conjunction between the typology under consideration and the results of the empirical survey.

\section{Comments and conclusion}

The overall approach to management has experienced major challenges in recent years. The old and essentially resourcebased outlook is well defined by Certo:

'... management is defined as the process of reaching organizational goals by working with and through people and other organizational resources' (1983: 9).

In this approach the dominant elements are 'goals' to be best attained by utilizing available 'resources', that is internal efficiency is of paramount importance. This inward look has earlier been cited as the result of the fact that $85 \%$ of CEOs in South Africa are accountants (Ekman, 1989: 12) - the question may be posed as to what extent this may still be valid today, and thus probably a contributing factor to relatively scant attention being afforded to aspects of environmental change.

In today's turbulent environmental conditions, however, this approach need to be supplemented (not replaced!) with external effectiveness, in other words, being efficient but with a view to strengthening the organization's external strategic posture, now and especially for the future. In this regard the most essential requirement for any strategy is the 'Goodness of Fit Test' (Thompson \& Strickland, 1996: 53) or the need for a strategy to be well-matched to both the internal and external situations. Without this situational fit, a strategy's appropriateness in terms of gaining a sustainable competitive advantage (Competitive Advantage Test) and thus improved output performance (Performance Test), must indeed be regarded as very suspect.

Based on the findings of this survey it is evident that South African organizations do not seem to be able to pass the 'Goodness of Fit Test'. Their emphasis is on shorter term issues (efficiency) rather than a long-term focus and strategic positioning (effectiveness). This situation makes South African organizations extremely vulnerable to global competitors moving into the local markets and, at the same time, place them at considerable disadvantage in order to themselves gaining global competitiveness. A similar conclusion was reached by the Johannesburg-based marketing consultancy, the NPL Group (Saturday Argus, April 6/7, 1996: 7).

Furthermore, being apparently divorced from developments in the environment result in an inability to 'change with the times' - strategic transformation. That South African organizations are unable to successfully implement transformation was clearly confirmed by a recent survey conducted by Ernst and Young and Insight Customer Satisfaction Consultants (Saturday Argus, 17-18/8/96: 24). In this regard it is interesting to note that the Ernst \& Young study (Ernst \& Young/Insight, 1996: $x$ ) furthermore observed that the human resource community should 'enhance their relevance and contribution' to strategic transformation and that this concurs with the low 
importance respondence to this survey accorded to the $\mathrm{Hu}$ man resources function during high levels of perceived environmental uncertainty.

The observed remoteness from the market place and an inability to respond (transform) to environmental change will also inhibit the development of the modern-day network type organizations amongst South African organizations - here 'Firms must adapt with increasing speed to market pressures and competitors innovations, ...' (Snow, Miles \& Coleman, 1992: 6).

The overall conclusion is obvious - South African organizations do not align themselves with changing environmental conditions, resulting in lip service being paid to real change or transformation and thus inhibiting their ability to gain sustainable competitive advantage, and resultant profitability. both on local and foreign markets.

\section{Recommendation}

South African organizations should make a much greater effort to align themselves with changes in the environment and then implementing the adjustments or transformation required. This will not only benefit the individual organization but, given the importance of appropriate business strategies for the overall prosperity and advancement of a country per se (Porter, 1990: 107-124), will enhance the competitiveness and stature of the South African domestic economy, not only locally but also as a global force.

\section{Suggestions for further research}

The original problem statement still persists with inconclusive empirical evidence regarding the validity of the total and integrated framework proposed by Miles \& Snow. Further research appears obvious, particularly when viewed against the benchmark article by Bernard Taylor where he concludes that: 'to achieve superior competitive performance requires an integrated approach to business, ...' (1986: 18). However, at this juncture and after so much research, one is left to ponder the observation by Hambrick (1983: 7) where he lamented that the Miles \& Snow strategic types '... may have yielded the appearances of a more powerful typology than may in fact exist'.

As far as the South African situation is concerned, research should probably be addressed at establishing the reasons for the apparent apathy towards proper external alignment. One cause may be related to information technology systems which may be too internally focussed but should rather be driven by the demands of the external business environment (Tapscott \& Carson, 1993). Next, ways to overcome the inward-looking attitude should be investigated together with developing and refining relevant implementation and strategic control tools, for example the Balanced scorecard (Kaplan \& Norton, 1992, 1993 \& 1996).

A paradigm shift or simply new clothes for the emperor? Based on this study which included both an in-depth literature scan of the Miles \& Snow framework, as well as an empirical survey, it would seem that no fundamental issues arise to challenge the basic validity of the conventional approach to strategy, even under turbulent environmental conditions. According to Byars, Rue \& Zahra (1996: 5): 'an orderly approach to change improves the odds of good performance ...'
This view is also encapsulated in an article by Stacey (1993), 'Strategy as order emerging from chaos'. Furthermore, a simulation model has already been developed and applied (successfully) in practice to develop strategic guidelines and managerial decision rules to cope with chaos conditions in the environment (Levy, 1994).

Probably a totally new paradigm is not required after all:

'this dominant strategy frame is not wrong ... every company must ultimately effect a fit between its resources and the (external) opportunities it pursues, ... all go without saying' (Hamel \& Prahalad, 1993: 77) and, according to Porter (1996) achieving external sustainable positioning (fit) results from a flexible internal framework developed around core competencies and allowing for tradeoff decisions or choices to establish optimal fit among internal activity systems. However, it is conceiveable that the traditional frame of strategic reference does require some additional 'with-it clothing' to make it more contemporary and dynamic in terms of continuous change, flexibility and adaptability, that is the concept of strategizing and building a value constellation of activities (Nakamura, 1997:8). The moderating effects of inter alia chaos theory, intrapreneurship and proper management of power and politics need to be addressed in this regard. Inserting the principle of 'strategic stretch' into conventional strategy as suggested by Hamel \& Prahalad (1993) as well as incorporating the increasingly more important and relatively flexible (based on scenarios) concept of issues management (Wilson, 1994: 22) into the conventional model (Camillus \& Datta, 1991) no doubt represents the beginning of a new 'wardrobe for strategic management'. This type of approach which is deviating from the mechanistic has already been described as 'managing with dual strategies' (Hamel, 1993).

\section{Note}

1. For present purposes the specific relationship, and resultant generic strategy, between the competitive environement per se and the organization is not explored. See Porter (1980).

\section{Acknowledgement}

The author wishes to thank Ms Zandra Warnick who did the data-entering during her spare time and Prof E v/d M Smit who did the computer data processing and also made valuable suggestions and contributions with regard to the statistical analyses and interpretation. Also, a very special word of thanks is due to Mrs Henritte Swart and her staff at the library for the major contribution which they have made to this research.

\section{References}

Abell, D.F. 1993. Managing with dual strategies. New York: The Free Press, p.292.

Abell, D.F. \& Hammond, J.S. 1979. Strategic market planning: problems and analytical approaches. Inglewood Cliffs, New Jersey: Prentice-Hall, Inc., p.527.

Argus, Saturday. 1996. S.A. business must transform or die, Business section, August 17/18: 2.

Boyd (Jr), H.W., Walker (Jr), O.C. \& Larréché, J-C. 1995. Marketing management - a strategic approach with a global orientation. 2nd Edition. Chicago: Irwin, p.555. 
Camillus, J.C. \& Datta, D.K. 1991. Managing strategic issues in a turbulent environment, Long Range Planning. 24 (2): 67-74.

Certo, S.C. 1983. Principles of modern management. 2nd Edition. Dubugue, Iowa: Wm. C. Brown Company Publishers, p.579.

Child, J. 1972. Organisational structure, environment and performance: the role of strategic choice, Sociology Year, 6(1): 1-22.

Clayton, C. 1996. A bleak view of the future of S.A. business, Saturday Argus, Business Section, April 6/7: 7.

Conant, J.S., Mokwa, M.P. \& Varadarajan, P.R. 1990. Strategic types, distinctive marketing competencies and organizational performance: a multiple measure-based study, Strategic Management Journal, 11(5): 365-383.

Dess, G.G. \& Robinson, R.B. 1984. Measuring organizational performance in the absence of objective measures: the case of the privately-held firm and conglomerate business unit, Strategic Management Journal, 5(3): 265-273.

Ekman, B. 1989. Getting on the ball - the corporate winning process. Cape Town: Juta \& Co, Ltd., p.99.

Emst \& Young/Insight. 1996. Business transformation in South Africa.

Gould, M. \& Campbell, A. 1989. Strategies and styles. Oxford: Blackwell, p.374.

Hambrick, D.C. 1981. Environment, strategy and power within top management teams, Administrative Science Quarterly, 26(2): 253-276.

Hambrick, D.C. 1982. Environmental scanning and organizational strategy, Strategic Management Journal, 3(2): 159-174.

Hambrick, D.C. 1983. Some tests of the effectiveness and functional attributes of Miles \& Snow's strategic types, Academy of Management Journal, 26(1): 5-26.

Hamel, G. \& Prahalad, C.K. 1993. Strategy as stretch and leverage, Harvard Business Review, 71(2): 75-84.

Hanigan, K.R. 1983. Research methodologies for contingency approaches to business strategy, Academy of Management Review, 8(3): 398-405.

Hardy, C. 1994. Managing strategic action. London: Sage Publications, p.468.

Hitt, M.A., Ireland, R.D. \& Palia, K.A. 1982. Industrial furms' grand strategy and functional importance: moderating effects of technology and uncertainty, Academy of Management Journal, 25(2): 265-298.

Hooley, G.J., Lynch, J.E. \& Sheppard, J. 1990. The marketing concept: putting the theory into practice, European Journal of Marketing, 24(9): 7-23.

Kaplan, R.S. \& Norton, D.P. 1992. The Balanced Scorecard - measures that drive performance, Harvard Business Review, 70(1): 7179.

Kaplan, R.S. \& Norton, D.P. 1993. Putting the Balanced Scorecard to work, Harvard Business Review, 71(5): 134-147.

Kaplan, R.S. \& Norton, D.P. 1996. Using the Balanced Scorecard as a strategic management system, Harvard Business Review, 74(1): 75-85.

Kress, G. 1982. Marketing research. 2nd Edition. Reston Virginia: Reston Publishing Company, Inc., p.427.

Laubscher, I. 1994. An exploratory investigation into the nature, scope and strategies of the service industry - with particular reference to the Western Cape region. Study Project, Bellville: Graduate School of Business, University of Stellenbosch, p.139.

Levy, D. 1994. Chaos theory and strategy: theory, application, and managerial implications, Strategic Management Journal, 15: 167178.
McDaniel, S.W. \& Kolari, J.W. 1987. Marketing strategy implica tions of the Miles \& Snow strategic typology, Journal of Marter. ing, 51(4): 19-30.

Miles, R.E. \& Snow, C.C. 1978. Organisational strategy structure and process. New York: McGraw-Hill Book Company, p.273.

Miles, R.E. \& Snow, C.C. 1984. Fit, failure and the Hall of Fame, California Management Review, XXVI(3): 10-28.

Miles, R.E., Snow, C.C. \& Pfeffer, J. 1974. Organisation - environ ment: concepts and issues, Industrial Relations, 13(October): 244-264.

Mintzberg, H. 1978. Patterns in strategy formation, Management Science, 24(6): 934-948.

Mintzberg, H. \& Waters, J.A. 1985. Of strategies, deliberate and emergent, Strategic Management Journal, 6(3): 257-272.

Nakamura, Gen-Ichi. 1997. New frontiers of strategic management for corporate executives, Strategic Change, 6: 3-15.

Narver, J.C. \& Slater, S.F. 1990 . The effect of a market orientation on business profitability, Journal of Marketing, 54(4): 20-35.

Nutt, P.C. \& Bachoff, R.W. 1992. Strategic management of public and third sector organisations. San Francisco: Jossey-Bass Publishers, p.486.

Pearce, J., Robbins, D.C. \& Robinson, R.B. 1987. The impact of grand strategy and planning formality on financial performance, Strategic Management Journal, 8(2): 125-134.

Porter, M.E. 1980. Competitive strategy. New York: The Free Press, p.396.

Porter, M.E. 1990. The competitive advantage of nations. New York: The Free Press, 557p.

Porter, M.E. 1996. What is strategy? Harvard Business Review, 74(6): 61-78.

Segev, E. 1989. A systematic comparative analysis and synthesis of two business-level strategic typologies, Strategic Management Journal, 10(4): 487-504.

Shortell, S.M. \& Zajac, E.J. 1990. Perceptual and archival measures of Miles \& Snow's strategic types: a comprebensive assessment of reliability and validity, Academy of Management Journal, 33(4): 817-832.

Snow, C.C. \& Hambrick, D.C. 1980 . Measuring organizational strategies: some theoretical and methodological problems, Academy of Management Review, 5(4): 527-538.

Snow, C.C. \& Hrebiniak, L.G. 1980. Strategy, distinctive competence, and organisational performance, Administrative Science Quarterly, 25(2): 317-334.

Snow, C.C., Miles, R.E. \& Coleman (Jr), H.J. 1992. Managing 21st century network organizations, Organisational Dynamics, 20(3): 5-20.

Stacey, R. 1993. Strategy as order emerging from chaos, Long Range Planning, 2(1): 10-17.

Stacey, R.D. 1996. Strategic management and organisational dynamics. 2nd Edition. London: Pitman Publishing, p.520.

Tapscott, D. \& Caston, A. 1993. Paradigm shift - the new promise of information technology. New York: McGraw-Hill, Inc., p.337.

Taylor, B. 1986. Corporate planning for the 1990s: the new frontiers, Long Range Planning, 19(6): 13-18.

Thompson (Jr), A.A. \& Strickland, A.J. 1996. Strategic management. 9th Edition. Chicago: Irwin, p.1035.

Wilson, I. 1994. Strategic planning isn't dead - it changed, Long Range Planning, 27(4): 12-24.

Wheatley, M.J. 1994. Leadership and the new science. San Francisco: Berret-Koehler Publishers, Inc., p. 166. 